\title{
Gerakan Sosial Digital "Warga Bantu Warga” Sebagai Respons Masyarakat Indonesia dalam Menghadapi Pandemi
}

\author{
Ayu Kartika \\ Mahasiswa Program Doktor Sosiologi Universitas Brawijaya \\ akakartika@gmail.com
}

Keywords:

Covid-19; pandemic;

digital social

movement; Warga

Bantu Warga;

resilience

Covid-19; pandemi; gerakan sosial

digital; Warga

Bantu Warga; resiliensi

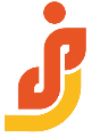

BRAWIJAYA JOURNAL of SOCIAL SCIENCE

Vol. 1, No. 1, 2021

DOI:

https://doi.org/10.2 1776/ub.bjss.2021.0

$\underline{01.01 .2}$

Submitted: 2021-11-15

Accepted: 2021-12-05

\section{Abstract}

The Covid-19 pandemic has had a significant impact on all aspects of people's lives. Economic crises and social problems are inevitable and touch all levels of society, especially the lower classes. Even so, the Indonesian people have proven resilience and empowerment in the face of the Covid-19 pandemic. The existence of the internet and social media has encouraged the emergence of digital social movements, one of which is Warga Bantu Warga (Citizens Helping Citizens). Through this movement, the Indonesian people work together, collaborate, and show solidarity in helping others overcome difficulties due to the pandemic. The movement seemed to bind the community collectively and direct their actions in actions that did not only occur on a regional scale, but also nationally in all provinces in Indonesia. Although it is a movement that was born and proceeds at the digital level, in fact this movement has produced great benefits for the community, and it still persists to this day when Covid-19 cases have decreased. This phenomenon is studied through a framing approach, so that it can be seen how the framing of events in the Warga Bantu Warga movement is able to harmonize understanding and mobilize social media users to join the Warga Bantu Warga movement.

\section{Abstrak}

Pandemi Covid-19 telah menimbulkan dampak yang signifikan dalam segala aspek kehidupan masyarakat. Krisis ekonomi dan permasalahan sosial menjadi hal yang terelakkan dan menyentuh semua lapisan masyarakat, terutama masyarakat lapis bawah. Walaupun begitu, masyarakat Indonesia telah membuktikan resiliensi dan keberdayaan dalam menghadapi pandemi Covid19. Adanya internet dan media sosial telah mendorong kemunculan gerakan sosial digital yang salah satunya adalah Warga Bantu Warga. Melalui gerakan 
ini, masyarakat Indonesia saling bergotong royong, berkolaborasi, dan menunjukkan solidaritas dalam membantu sesama mengatasi kesusahan akibat pandemi. Gerakan tersebut seakan mengikat masyarakat secara kolektif dan mengarahkan tindakannya dalam aksi yang tidak hanya terjadi pada skala regional, tetapi hingga lingkup nasional di seluruh provinsi di Indonesia. Walaupun merupakan gerakan yang lahir dan berproses pada tataran digital, nyatanya gerakan ini telah menghasilkan kemanfaatan yang besar pada masyarakat, dan masih bertahan hingga saat ini di kala kasus Covid-19 telah menurun. Fenomena ini dikaji melalui pendekatan framing, sehingga dapat diketahui bagaimana pembingkaian peristiwa pada gerakan Warga Bantu Warga mampu menyelaraskan pemahaman dan memobilisasi para pengguna media sosial untuk turut bergabung dalam gerakan Warga Bantu Warga.

\section{Pendahuluan}

Termaktub Coronavirus Disease atau yang biasa disebut Covid-19 telah menjadi pandemi yang sampai saat ini masih mempengaruhi segala aspek kehidupan masyarakat di seluruh dunia. Bermula dari kasus di Wuhan, China di penghujung tahun 2019 hingga merambah pada belahan dunia lainnya, termasuk Indonesia. Hingga saat ini, setelah lebih dari satu tahun dari awal terjadinya pandemi, total kasus di seluruh dunia telah mencapai 253 juta dengan 5,1 juta kasus meninggal dunia (data per 14 November 2021). Saat ini kasus di Indonesia sendiri telah mencapai total 4,25 juta kasus dengan 144 ribu kasus meninggal dunia.

Pandemi yang telah menjadi fenomena global telah memberikan dampak yang dahsyat dari segala sendi kehidupan, dan tak terkecuali bagi Indonesia sendiri. Dari segi ekonomi, sudah jelas bahwa pandemi telah berdampak pada krisis ekonomi bahkan pada tahap selanjutnya menjadi resesi. Upaya penanganan Covid-19 pun menjadi beban yang besar terhadap APBN Indonesia. Sedangkan dari aspek sosial juga terjadi perubahan besar dalam interaksi masyarakat. Semula masyarakat Indonesia terbiasa hidup dan berinteraksi secara komunal, tetapi sejak pandemi masyarakat harus membiasakan diri dengan kebiasaan baru yang disebut "new normal". Ajakan untuk melakukan protokol kesehatan secara ketat, di rumah saja, batasi mobilitas, bahkan banyak institusi yang berhenti beroperasi membuat polemik sosial menjadi sesuatu yang tak terelakkan. Perubahan secara drastis dalam waktu yang spontan tersebut sontak membuat banyak lapisan masyarakat mengalami permasalahan ekonomi, sosial, maupun psikologis, seperti kehilangan mata pencaharian, mengalami perubahan kelas sosial serta adanya ketidakpercayaan pada pemerintah terhadap penanganan pandemi. Merujuk pada pendapat Mas'Udi dan Winanti (2020, h.2) bahwa perubahan yang terjadi akibat Covid-19 terlihat pada berbagai aspek kehidupan baik pada perilaku individu, respon komunitas, penyelenggaraan bisnis dan ekonomi, tata kelola negara, sampai pada relasi secara global. Perubahan tersebut juga merupakan implikasi dari pengaturan selama masa tanggap darurat Covid-19 seperti diberlakukannya lockdown dan isolasi level komunitas, social distancing, mekanisme work from home, distancing learning, efisiensi, dan 
refocusing sumber daya, serta penyesuaian lainnya yang kemudian menjadi suatu kebiasaan baru.

Dampak yang dirasakan oleh masyarakat beserta kebijakan pemerintah yang kurang tepat dalam mengatasi permasalahan kesehatan, ekonomi dan sosial akibat pandemi, dan diperparah oleh kasus korupsi Bansos yang seharusnya diperuntukkan bagi masyarakat terdampak, semakin menambah rentetan permasalahan akibat Covid19. Walaupun begitu, masyarakat tidak kehilangan cara untuk mempertahankan resiliensi dan berupaya untuk melakukan perubahan. Menurut Keck dan Sakdapolrak, resiliensi sosial merujuk pada kemampuan atau kapasitas suatu entitas sosial, baik itu individu, organisasi, atau komunitas untuk mentolerir, menyerap, mengatasi, dan beradaptasi dengan berbagai jenis lingkungan dan ancaman sosial (Supriatna, E., Irwandi, \& Sari, A. L, 2020, h. 21). Dalam hal ini digitalisasi teknologi informasi dan komunikasi membantu dalam menyebarkan narasi bahwa masyarakat bukan semata korban dari pandemi, tetapi masyarakat juga mampu menjadi penggerak perubahan dalam membantu sesama menghadapi pandemi.

Gerakan "Warga Bantu Warga" menggema di jagat virtual, terutama di media sosial, seperti pada Twitter maupun Instagram. Ungkapan yang sederhana tetapi dalam secara makna, mengenai bagaimana masyarakat mengerahkan dirinya sendiri demi kepentingan luas atas dasar sama-sama menghadapi kesulitan akibat pandemi. Melalui gerakan tersebut masyarakat menunjukkan diri untuk tidak menunggu dan bergantung pada pemerintah dalam menghadapi dampak yang ditimbulkan oleh pandemi. Solidaritas di antara masyarakat tumbuh dan menguat, direalisasikan melalui sebuah gerakan sosial sebagai respon atas pandemi. Dilansir dari jajak pendapat yang dilakukan oleh media Kompas pada pertengahan Mei tahun 2020, dapat dilihat menguatnya solidaritas publik, di mana 64 persen responden mengatakan masyarakat semakin peduli saat pandemi ini. Begitu banyak kemunculan inisiatif gerakan swadaya yang dipelopori oleh baik perorangan maupun public figure, komunitas masyarakat, organisasi sosial, hingga perusahaan, bahkan di tingkat akar rumput, serta berbagai inisiatif dari mana pun dan dalam beragam bentuk (Sujito, 2020, h. 257). Lebih lanjut Sujito (2020, h. 257) memaparkan bahwa ketika pandemi begitu mendalam dan meluas, kemudian mesin sistem sosial ekonomi mandeg, maka jejaring masyarakat sebagai sistem lokal-lah yang akan mengambil alih sementara peranan penyelamatan sosial ekonomi layaknya penopang agar sistem tidak benar-benar macet. Dalam hal ini, baik individu, kelompok, maupun komunitas dari berbagai macam latar belakang kepentingan muncul dan melakukan tindakan kemanusiaan.

Aksi Warga Bantu Warga mulai ramai beredar di media sosial, baik Twitter maupun Instagram. Bantuan yang diberikan pun beragam, mulai dari bantuan pangan dan obatobatan bagi yang membutuhkan, bantuan bagi UMKM, pendampingan psikologis, sampai pada informasi medis seperti ketersediaan rumah sakit, ambulans, maupun donor konvalesen. Gerakan ini juga menyebar ke seluruh provinsi di Indonesia. Dilansir dari liputan Tempo pada situs webnya, sebuah artikel berjudul "Pandemi Covid-19, Gerakan Solidaritas Warga Bantu Warga Meningkat" memaparkan bahwa kondisi yang sulit 
mendorong terbentuknya swadaya warga dalam upaya penanganan pandemi Covid-19. Terlebih kondisi kian sulit karena berbagai kebijakan pemerintah yang menurut beberapa pihak, belum mampu mengakomodasi kebutuhan rakyat sepenuhnya. Sehingga sebagai akibatnya, rakyat pun tergerak untuk saling membantu di bawah payung narasi Warga Bantu Warga.

Lebih lanjut, aksi dalam gerakan sosial Warga Bantu Warga terus meningkat dan selalu memberikan informasi baru dan bantuan setiap harinya. Hal itu bisa dipantau melalui unggahan beserta penggunaan tagar (\#)wargabantuwarga yang diunggah dalam media sosial. Bahkan hingga saat ini di saat kasus Covid-19 sudah turun, gerakan tersebut masih menunjukkan eksistensinya. Walaupun mulanya Warga Bantu Warga ditujukan sebagai suatu wadah informasi digital terkait Covid-19, pada akhirnya istilah Warga Bantu Warga tidak hanya sebagai nama situs pencarian informasi, namun telah bertransformasi menjadi sebuah gerakan masyarakat sipil. Demi menginstitusionalisasikan hal tersebut, terdapat setidaknya 23 lembaga, mulai dari lembaga perguruan tinggi, media, medis, maupun fundraising yang menamakan dirinya sebagai kolaborator dalam gerakan ini. Sehingga, seruan berupa tagar dan unggahan bantuan maupun informasi di media sosial yang semula sifatnya sporadis, dengan adanya situs tersebut bantuan yang ditawarkan dapat diorganisir menjadi lebih sistematis sehingga memudahkan pengguna situs dalam mengakses informasi ataupun bantuan yang dibutuhkan.

Bagaimanapun, untuk mewujudkan cakupan yang lebih luas dan aksi yang berkelanjutan, solidaritas masyarakat dalam gerakan sosial juga memerlukan intervensi dan kontribusi dari lembaga-lembaga profesional. Sebagaimana yang dipaparkan oleh Sujito (2020, h. 258), bahwa keragaman praktik-praktik solidaritas sosial baik di level kampung, desa, maupun komunitas masih cenderung bersifat reaksioner (spontanitas). Dikarenakan sifatnya yang masih reaksioner dan spontan, maka aksi kolektivitas masyarakat dalam mengatasi bencana tersebut masih berpola subsisten, atau hanya bersifat sementara dalam jangka waktu yang pendek. Sehingga diperlukan intervensi atau fasilitas kelembagaan untuk keberlangsungan dan pemberdayaan dalam jangka panjang. Melalui kolaborasi dari banyak pihak, hingga saat ini gerakan Warga Bantu Warga telah berhasil mengumpulkan dana bantuan senilai Rp. 2.887.042.236,00. Selain itu melalui gerakan ini terdapat relawan sejumlah 7117 yang tersebar di seluruh Indonesia dalam memberikan bantuan pada masyarakat. Melalui gerakan ini dapat dilihat bagaimana persebaran informasi melalui media sosial dapat mendorong terjadinya dan kesuksesan gerakan sosial.

Dalam melihat gerakan sosial tersebut terdapat banyak perspektif yang bisa digunakan, salah satunya adalah pendekatan framing. Dalam konteks pandemi, sangat dimungkinkan bagi masyarakat untuk memiliki pemahaman yang berbeda dalam memaknai dan merespon pandemi. Beberapa orang bisa saja menafikkan Covid-19 dan menganggap penyakit tersebut tak lebih hanya flu biasa. Sementara yang lain gencar menganggap bahwa pandemi adalah sebuah konspirasi global yang dimainkan elit demi keuntungan segelintir pihak. Adapun masyarakat yang percaya pada Covid-19 sebagai 
penyakit mematikan namun kecewa dan menyalahkan pemerintah atas berbagai keterbatasan dalam penanganan pandemi. Atas perbedaan pemahaman tersebut, satu hal yang menarik adalah bahwa gerakan Warga Bantu Warga mampu menyelaraskan pemahaman masyarakat untuk turut andil dan bergerak dalam memberikan solusi sebagai respon pandemi. Sejak kemunculannya pada Juli 2021, hingga saat ini gerakan Warga Bantu Warga masih menunjukkan eksistensinya. Maka pendekatan framing dirasa tepat untuk memahami gerakan ini dan melihat bagaimana pembingkaian peristiwa maupun narasi atas pandemi yang disebarluaskan pada media sosial mampu menyelaraskan pemahaman dan menjadi sebuah gerakan sosial digital, yaitu Warga Bantu Warga.

\section{Metode Penelitian}

Penelitian ini menggunakan analisis framing yang merupakan salah satu dari metode analisis teks dalam paradigma konstruksionis. Objek yang diteliti merupakan unggahan pada platform Twitter, baik dari kolaborator gerakan maupun dari masyarakat sipil yang terkait dengan gerakan Warga Bantu Warga dalam kurun waktu Juli 2021 hingga Oktober 2021. Unggahan tersebut dapat berupa teks, gambar, maupun video.

\section{Hasil dan Pembahasan}

\subsection{Resiliensi Sosial}

Resiliensi merupakan konsep teoritis yang memungkinkan kita untuk menjelaskan dan bahkan memprediksi variabilitas antara manusia dalam kemampuan mereka untuk menghadapi kesulitan (Kimhi, S.; Eshel, Y.; Marciano, H.; Adini, 2021, h.1). Menurut Brunnermeier (2021, h. 8), resiliensi adalah tentang kemampuan untuk bereaksi setelah hantaman, kemampuan untuk bangkit kembali atau, dalam istilah formal untuk "memandang kembali". Kemampuan untuk pulih itu menyiratkan kebutuhan untuk memfasilitasi adaptasi. Kemampuan untuk beradaptasi dan berubah akan memperkuat resiliensi (Brunnermeier, 2021, h.8). Resiliensi sosial juga didefinisikan sebagai kapasitas aktor untuk mengakses modal, untuk tidak hanya mengatasi dan menyesuaikan diri dengan kondisi yang merugikan, tetapi juga mencari dan membuat opsi, dengan demikian mampu mengembangkan peningkatan kompetensi dalam menghadapi ancaman (Obrist, Pfeiffer, dan Henley, 2010, h.285). Semua definisi tentang resiliensi sosial menyangkut sosial entitas, baik individu, organisasi atau komunitas, serta kemampuan atau kapasitas mereka untuk menoleransi, menyerap, mengatasi, dan menyesuaikan diri dengan berbagai macam ancaman lingkungan dan sosial (Keck, Saldaporak, 2013, h.8). Melalui definisi-definisi tersebut dapat disimpulkan bahwa resiliensi sosial berkaitan dengan kemampuan masyarakat untuk tidak sekedar beradaptasi, melainkan kemampuan untuk bangkit dan membuat pilihan dalam menghadapi suatu kesulitan.

Sejak merebaknya virus Covid-19, resiliensi menjadi hal penting yang harus diupayakan untuk menghadapi krisis multidimensi yang terjadi. Gerakan Warga Bantu Warga dapat digolongkan sebagai respon masyarakat Indonesia dalam menghadapi 
berbagai dampak yang diakibatkan oleh pandemi. Melalui gerakan ini, masyarakat tidak hanya berusaha untuk beradaptasi dengan pandemi dan norma baru, melainkan juga berupaya untuk menyelesaikan berbagai persoalan sosial dan ekonomi secara kolektif melalui pemanfaatan teknologi informasi, khususnya media sosial.

\subsection{Gerakan Sosial Digital}

Tingginya jumlah pengguna media sosial di Indonesia telah mempengaruhi berbagai pola relasi dan aktivitas masyarakat, salah satunya adalah kolektivitas maupun gerakan sosial yang muncul pada era digitalisasi informasi dan komunikasi. Beberapa fenomena yang terjadi di Indonesia telah memperlihatkan adanya gerakan sosial yang dalam proses dan penyebarannya termediasi oleh internet. Gerakan sosial digital banyak terjadi pada platform media sosial, seperti Facebook, Twitter, maupun Instagram. 2 contoh besar dalam gerakan sosial digital di Indonesia antara lain kasus 'cicak vs buaya' yang merujuk pada konflik KPK dan Kepolisian, dan gerakan 'koin untuk Prita'. Kedua kasus tersebut memperlihatkan besarnya atensi dari masyarakat sebagai pengguna media sosial yang menjalin solidaritas sebagai salah satu sikap terhadap persoalan yang dianggap sebagai permasalahan bersama. Beberapa akademisi melihat teknologi digital memiliki dampak positif bagi gerakan sosial. Merujuk pada penelitian oleh Lim (2018), evolusi media sosial telah mempengaruhi gerakan gerakan sosial dengan menyediakan platform yang mudah diakses dimana pengguna dapat mempromosikan kegiatan, mengorganisir protes, membagi informasi, maupun menyebarkan rumor. Hasil positif juga dikemukakan berdasarkan penelitian mengenai akademi berbagi sebagai sebuah gerakan sosial digital di Indonesia. Dari penelitian yang dilakukan oleh Ismail (2012) ditemukan bahwa gerakan sosial yang dihasilkan di internet tidak hanya sebatas pada click activism maupun share information, tetapi kolaborasi dan kombinasi ruang 'real' dan 'virtual' telah memberikan konteks dan validasi dalam melakukan gerakan sosial. Selain itu gerakan sosial yang termediasi oleh internet telah memberikan sebuah konsep baru yaitu online social movement. Gerakan sosial yang berlangsung secara digital, atau termediasi oleh internet dianggap sebagai pilihan masyarakat kontemporer saat ini dalam melakukan aktivisme. Dengan meningkatnya penetrasi penggunaan media sosial, memberikan dampak signifikan dan menjadi manifestasi bangkitnya masyarakat sipil dalam melakukan sesuatu yang baik dan bermanfaat bagi Indonesia. Pendapat tersebut juga sejalan dengan Castell dalam Carty (2015, h. 28-29) bahwa:

"The new ICT's invigorate an explosive type of informational politics, resulting in an new kind of civil society based on the electronic grassrooting of democracy. The diffusion of new technology prompts the development of horizontal networks of interactive communication through a many-to-many flow of communication."

Namun walaupun begitu beberapa pendapat lebih skeptis dengan menganggap bahwa dampak media digital terhadap gerakan sosial adalah sebuah utopia belaka. Seperti yang dikemukakan oleh Bimber dan Davis dalam Carty (2015, h. 30) yang 
mengistilahkan internet sebagai 'par execellence', sebuah medium bagi orang-orang untuk berinteraksi berdasarkan pilihan, seperti dengan orang yang dianggap berpikiran terbuka, yang hal ini akan berimplikasi pada fragmentasi dan polarisasi. Skeptisme terhadap gerakan sosial juga dibuktikan oleh salah satu penelitian yang dilakukan oleh Merlyna Lim pada tahun 2014. Melalui penelitiannya yang berjudul "Klik yang Tak Memantik: Aktivisme Media Sosial di Indonesia", ditemukan bahwa aktivisme media sosial menandai suatu periode inovasi dan eksperimen dalam penggunaan teknologi media baru dan budaya partisipatif. Ekspresi online, budaya populer, dipadukan dengan kegiatan sosial dapat menciptakan ranah-ranah bagi masyarakat Indonesia untuk berkumpul bersama. Namun, media sosial bukan ranah yang tepat untuk mendalami dan mencerna wacana yang kompleks atau isu-isu sulit. Aktivisme dalam media sosial dapat ditransformasikan menjadi gerakan politik apabila menganut asas-asas budaya konsumsi kontemporer, seperti kemasan ringan, selera tajuk berita, dan tampilan cuplikan. Aktivisme media sosial dinilai cenderung tergesa dan rapuh, yang artinya dapat muncul setiap menit tetapi seringkali hilang tanpa jejak, atau mungkin banyak diklik tetapi kurang memiliki perekat. Oleh karena itu hanya sedikit isu yang akan melahirkan gerakan besar di dunia maya. Kesuksesan gerakan dalam media sosial lebih memungkinkan jika dipopulerkan oleh narasi sederhana, melibatkan kegiatan beresiko rendah, dan sejalan dengan metanarasi dominan. Lebih lanjut, Lim (2014) menganggap bahwa kegiatan media sosial pada kalangan menengah perkotaan didominasi tujuan kesenangan maupun ekspresi diri. Temuan lainnya adalah bahwa media sosial tidak secara inheren mempromosikan keterlibatan sipil dan tidak selayaknya dianggap sebagai agen penyebab perubahan sosial dan demokrasi.

Berdasarkan pada penelitian-penelitian yang telah disebutkan sebelumnya, peneliti menganggap bahwa kajian mengenai gerakan sosial yang berlangsung pada tataran online merupakan fenomena yang layak dikaji dan masih membutuhkan penelitian-penelitian lebih lanjut terhadap aspek-aspek di dalamnya, terlebih terdapat dua kubu yang menganggap bahwa media sosial telah menjadi penggerak terhadap gerakan sosial digital, maupun pendapat yang menyatakan bahwa gerakan sosial secara digital tidak selalu berhasil dalam menghasilkan gerakan secara nyata dan berkelanjutan.

\subsection{Pendekatan Framing dan Gerakan Sosial}

Terdapat Terdapat banyak pendekatan dalam mengkaji gerakan sosial sebagai sebuah fenomena, salah satunya adalah pendekatan framing. Framing merupakan pendekatan yang digunakan untuk melihat bagaimana realitas dibentuk dan dikonstruksi oleh media (Eriyanto, 2002, h.66). Menurut Robert N Entman, framing merupakan suatu proses seleksi dari berbagai aspek realitas sehingga bagian tertentu dari peristiwa itu lebih menonjol dibandingkan aspek lain (Eriyanto, 2002, h.66). Walaupun begitu, pendekatan ini tidak hanya dapat digunakan untuk mengkaji suatu pemberitaan pada media, tetapi juga dapat digunakan untuk menganalisis suatu gerakan sosial. Merujuk pada Benford dan Snow (2019, h. 396) bingkai aksi kolektif merupakan produk yang 
dihasilkan dari aktivitas pembingkaian dalam arena gerakan sosial. Pembingkaian tersebut merupakan seperangkat keyakinan dan makna berorientasi aksi yang relatif koheren yang melegitimasi dan mengilhami kampanye maupun kegiatan gerakan sosial. Seperti layaknya bingkai interpretasi sehari-hari, bingkai tindakan kolektif juga memusatkan perhatian, mengartikulasikan, dan menguraikan elemen-elemen di dalam bingkai, dan sering mengelaborasikan makna yang terkait dengan objek perhatian. Walaupun begitu, pembingkaian pada aksi kolektif berbeda dengan bingkai interaksi sehari-hari dalam hal fungsi, yakni untuk memobilisasi atau mengaktifkan pengikut gerakan sehingga mereka bergerak, mobilisasi aksi, untuk mengubah pengamat menjadi pengikut sehingga memperluas basis gerakan (mobilisasi konsensus); dan untuk menetralisir atau mendemobilisasi musuh (counter-mobilisasi).

\subsection{Analisis Framingterhadap Gerakan Sosial Warga Bantu Warga}

Pemilihan Dari sejumlah data yang didapatkan melalui unggahan pada Twitter dalam gerakan Warga Bantu Warga selama kurun waktu Juli 2021 sampai dengan Oktober 2021, maka temuan dari data-data tersebut disajikan dalam tabel berikut sesuai dengan analisis framing dari Benford dan Snow:

Dari sejumlah data yang didapatkan melalui unggahan pada Twitter dalam gerakan Warga Bantu Warga selama kurun waktu Juli 2021 sampai dengan Oktober 2021, maka temuan dari data-data tersebut disajikan dalam tabel berikut sesuai dengan analisis framing dari Benford dan Snow:

Tabel 1. Analisis Framing dari Benford dan Snow

\begin{tabular}{|c|c|c|}
\hline \multicolumn{3}{|c|}{$\begin{array}{l}\text { Core Framing: Kebangkitan masyarakat sipil untuk tangguh dan berdaya dalam } \\
\text { menghadapi pandemi Covid-19 }\end{array}$} \\
\hline Gotong royong & $\begin{array}{l}\text { 1. Kolaborasi } \\
\text { masyarakat }\end{array}$ & $\begin{array}{l}\text { 1. Solidaritas } \\
\text { masyarakat }\end{array}$ \\
\hline $\begin{array}{l}\text { Diagnostic Framing: } \\
\text { Banyaknya masyarakat } \\
\text { yang mengalami kesulitan } \\
\text { akibat dari Pandemi Covid-19 }\end{array}$ & \begin{tabular}{|l} 
Diagnostic \\
Informing: \\
sering bersifat sporadis dan \\
tidak sistematis sehingga sulit \\
untuk mencari informasi yang \\
valid dalam media sosial
\end{tabular} & $\begin{array}{l}\text { Diagnostic Framing: } \\
\text { Banyaknya masyarakat } \\
\text { ang mengalami kesulitan } \\
\text { ibat dari Pandemi Covid-19 }\end{array}$ \\
\hline $\begin{array}{l}\text { Prognostic Framing: } \\
\text { - } \text { Donasi/ penggalangan } \\
\text { dana } \\
\text { - } \text { Menjadi penyedia } \\
\text { bantuan } \\
\text { - } \text { Menjadi relawan } \\
\text { - } \text { Menjadi mediator } \\
\text { - } \text { Menjadi penyebar } \\
\text { pesan secara digital }\end{array}$ & \begin{tabular}{|} 
Prognostic Framing: \\
Kolaborasi banyak pihak \\
professional untuk \\
mensukseskan dan \\
membuat gerakan \\
menjadi lebih sistematis, \\
salah satunya \\
meluncurkan situs \\
www.wargabantuwarga.c \\
om
\end{tabular} & $\begin{array}{l}\text { Prognostic Framing: } \\
\text {-Aksi solidaritas }\end{array}$ \\
\hline
\end{tabular}




$\left.\begin{array}{|c|c|c|}\hline \text { Menghentikan } & \begin{array}{c}\text { Kolaborasi banyak pihak } \\ \text { untuk bergerak secara } \\ \text { sistematis pada ranah } \\ \text { yang berbeda-beda, } \\ \text { seperti Kita Bisa dalam } \\ \text { hal penggalangan dana, } \\ \text { Indorelawan untuk } \\ \text { rekrutmen dan }\end{array} & \\ & \text { manajemen relawan, } \\ \text { maupun narasi dan mata } & \\ \text { najwa sebagai media } \\ \text { untuk mengangkat } \\ \text { menjadi pemberitaan } \\ \text { nasional. }\end{array}\right]$

Pada analisis pembingkaian yang digagas oleh Benford dan Snow, terdapat core framing (pembingkaian inti) dalam suatu aksi kolektif atau gerakan sosial. Pembingkaian inti tersebut terdiri dari 3 bagian, antara lain diagnostic framing, prognostic framing, dan motivational framing. Pembingkaian inti (core framing) dapat dipandang sebagai garis besar dari pandangan yang ingin ditekankan mengenai suatu fenomena. Seperti yang dikemukakan sebelumnya bahwa pendekatan framing memandang bahwa selalu terdapat pemilihan peristiwa, baik yang ditonjolkan maupun yang dihilangkan dalam membingkai suatu fenomena. Merujuk pada hasil temuan, core framing dalam gerakan Warga Bantu Warga adalah mengenai kebangkitan masyarakat sipil untuk tangguh dan berdaya dalam menghadapi pandemi Covid-19. Sehingga pandemi Covid-19 tidak dipandang hanya sebatas sebagai persoalan medis yang kemudian menimbulkan krisis di berbagai aspek, namun gerakan ini fokus menunjukkan dan mengkampanyekan nilainilai ketangguhan dan keberdayaan masyarakat sipil sebagai titik sentral yang selalu 
ditekankan pada setiap unggahan Twitter oleh pihak-pihak yang turut andil dalam gerakan Warga Bantu Warga. Ketangguhan dan keberdayaan masyarakat Indonesia dalam merespon dan menghadapi pandemi dijabarkan dalam beberapa hal, yaitu keyakinan dan aplikasi nilai gotong royong, kolaborasi masyarakat, solidaritas masyarakat, dan menanamkan persepsi bahwa masyarakat harus bergerak bersama.

Seperti yang telah dijabarkan sebelumnya, bahwa pembingkaian gerakan sosial terbagi ke dalam beberapa tataran, salah satunya adalah diagnostic framing. Diagnostic framing dapat dipahami sebagai sebuah identifikasi terhadap permasalahan, yaitu mengenai suatu peristiwa, aspek kehidupan sosial, ataupun sistem pemerintahan yang dipandang sebagai sesuatu yang bermasalah dan perlu diperbaiki atau diubah. Diagnostic framing berkaitan dengan "Apa yang salah atau siapa yang harus disalahkan?". Sehingga sebagai implikasinya, pada diagnostic framing seringkali sebuah gerakan sosial akan menekankan pembingkaian terhadap ketidakadilan ataupun viktimisasi. Walaupun begitu, berbeda dengan pendapat Benford dan Snow, bahwa pada gerakan ini tidak membingkai fenomena pandemi Covid-19 dengan menyalahkan atau menyoroti ketidakmampuan pemerintah dalam menangani pandemi, maupun skandal yang dilakukan pemerintah terkait korupsi Bansos oleh Menteri Sosial maupun tuduhan terhadap pemerintah mengenai skandal harga PCR.

Prognostic framing merupakan pembingkaian yang merujuk kepada solusi terhadap permasalahan yang telah dibingkai sebelumnya pada tataran diagnostic framing. Pada tataran prognostic framing, gerakan Warga Bantu Warga secara aktif dan konsisten selalu menunjukkan solusi berupa bantuan-bantuan yang bisa dilakukan, mulai dari donasi, menjadi penyedia bantuan, menjadi relawan, menjadi mediator, menjadi penyebar pesan, bahkan tindakan memutus rantai penyebaran hoaks. Semua solusi itu bukanlah aksi yang hanya bisa dilakukan secara offline, melainkan tindakan yang dapat dilakukan pada tataran online. Sebagai contoh, untuk menjadi relawan bisa hanya melalui gawai yang terhubung dengan internet untuk terus melakukan updating informasi keterisian rumah sakit. Selain itu, gerakan Warga Bantu Warga juga ingin menekankan bahwa solusi itu tidak selalu sulit, tapi bahkan bisa dilakukan hanya dengan satu klik, contohnya meretweet unggahan seseorang yang membutuhkan bantuan.

Motivational framing merupakan pembingkaian terhadap suatu fenomena dengan tujuan memersuasi atau menarik publik untuk berpartisipasi dan memiliki ikatan dengan gerakan sosial tersebut. Aktor-aktor dalam gerakan sosial merumuskan diksi-diksi yang digunakan untuk memprovokasi masyarakat untuk terlibat dalam isu-isu yang dipromosikan oleh gerakan sosial (Jamil, 2018, h. 176). Dalam gerakan Warga Bantu Warga, motivational framing dilakukan dengan cara menekankan aspek aspek yang membangkitkan optimisme, motivasi, inspirasi, empati, dan kebaikan. Dapat dikatakan bahwa dalam gerakan ini, para kolaborator maupun masyarakat yang tergabung dalam gerakan ini selalu menggunakan diksi-diksi yang menggugah rasa kemanusiaan para pengguna Twitter, seperti kebaikan, orang baik, kawan baik, inspirasi, bagikan kebahagiaan, semangat, dan panjang umur orang baik. 
Dari ketiga jenis pembingkaian tersebut gerakan Warga Bantu Warga secara dominan menekankan pada motivational framing. Hal ini ditujukan untuk menggerakkan perasaan para pengguna platform media sosial untuk berempati dan bersimpati terhadap pandemi Covid-19 sehingga tergerak untuk bergabung ke dalam gerakan Warga Bantu Warga. Selain iti, gerakan Warga Bantu Warga juga secara konsisten menekankan aspek prognostic framing dengan terus menerus menyoroti pada hal apa yang bisa diperbuat masyarakat untuk turut andil dalam gerakan tersebut. Sehingga para kolaborator maupun pengguna media sosial yang bergabung dalam gerakan ini sangat sering menekankan tindakan maupun program yang diperlihatkan sebagai solusi terhadap pandemi Covid-19. Sementara itu gerakan Warga Bantu Warga tidak terlalu menguatkan aspek diagnostic framing. Hal tersebut tercermin dari unggahan terkait Warga Bantu Warga yang tidak terlalu menyoroti pandemi Covid-19 sebagai sebuah persoalan, melainkan selalu lebih menekankan pada penguatan motivasi dan solusi yang ditawarkan demi atasi pandemi.

\subsection{Gerakan Sosial Digital sebagai Implementasi dari Kearifan Lokal (Local Wisdom)}

Permasalahan Dari analisis framing yang dilakukan, salah satu aspek yang ditekankan dalam gerakan warga bantu adalah pengaplikasian dan penguatan nilai lokal, yaitu gotong royong. Sejatinya, salah satu gagasan sentral dalam gerakan ini adalah gotong royong, yang kemudian diaplikasikan pada berbagai cakupan aksi, mulai dari pengumpulan donasi, bantuan untuk isolasi mandiri, penyebaran informasi terkait donor konvalesen, dan berbagai bantuan lainnya. Tidak hanya pada bantuan yang bersifat ekonomi tetapi rasa gotong royong juga diaplikasikan pada program-program yang bertujuan sebagai pendampingan secara sosial maupun psikologis, seperti telekonseling maupun ruang komunitas atma-go (salah satu kolaborator). Hal itu juga dipertegas oleh pernyataan salah satu inisiator gerakan yang mengemukakan bahwa nilai yang ingin diterapkan melalui gerakan Warga Bantu Warga adalah gotong royong.

Istilah gotong royong terdiri dari 2 suku kata yang berasal dari bahasa Jawa, yaitu gotong yang artinya pikul dan royong yang artinya bersama-sama. Sehingga secara tekstual, gotong royong dapat diartikan sebagai memikul bersama-sama. Secara kontekstual, maknanya dapat merujuk pada memikul tugas, beban, permasalahan maupun tanggung jawab bersama. Mengacu pada definisi dari Koentjaraningrat, gotong royong adalah pengerahan tenaga manusia tanpa bayaran untuk suatu proyek atau pekerjaan yang bermanfaat bagi umum atau yang berguna bagi pembangunan (Subagyo, 2021, h. 63). Sedangkan menurut Effendi (2013, h. 5) gotong-royong merupakan suatu paham yang dinamis, yang menggambarkan usaha bersama, amal, pekerjaan atau karya bersama, suatu perjuangan untuk bantu-membantu.

Gotong royong merupakan bentuk kearifan lokal yang dimiliki oleh masyarakat Indonesia. Beberapa ahli berpendapat bahwa gotong royong merupakan salah satu karakteristik yang terdapat pada masyarakat pertanian. Eric Wolf menyebutnya dengan istilah 'peasant community', sedangkan Ferdinand Tonnies menyebutnya sebagai 
gemeinschaft. Korelasi antara gotong royong dengan masyarakat pertanian dijabarkan oleh Subagyo (2012, h.64), bahwa suburnya tradisi kehidupan gotong royong di pedesaan tidak lepas karena kehidupan pertanian memerlukan kerjasama yang besar dalam upaya mengolah tanah, menanam, memelihara hingga memetik hasil panen. Nilai gotong royong sebagai kearifan lokal yang berakar kuat pada masyarakat pertanian dan pedesaan kemudian menimbulkan pertanyaan apakah nilai lokal tersebut akan mampu terus bertahan di tengah perubahan sosial masyarakat menuju modernitas dan mobilisasi ke arah masyarakat urban.

Melalui gerakan Warga Bantu Warga terbukti bahwa di tahun 2021 ini, di mana masyarakat Indonesia hidup dalam dunia modern yang penuh dengan kecanggihan teknologi dan bahkan gerakan sosial dapat berlangsung pada tataran virtual, kearifan lokal tersebut tetap mengakar kuat. Spirit gotong royong itu seakan bertransformasi pada tataran yang berbeda dengan pemahaman gotong royong pada masyarakat pedesaan. Saling membantu bukan lagi hanya dimaknai sebagai aksi pada tataran realitas offline yang dapat dilihat secara langsung, melainkan sikap gotong royong tersebut berpindah pada ranah yang virtual dengan bantuan internet dan media sosial. Selain itu data membuktikan bahwa banyak sekali masyarakat yang terlibat dalam gerakan Warga Bantu Warga ini adalah masyarakat urban dan anak-anak muda yang seringkali mendapat sentimen individualis layaknya karakteristik masyarakat perkotaan. Hal ini sejalan dengan pendapat Irfan (2016, h. 9), bahwa:

"Nilai-nilai gotong royong yang diduga pudar, ternyata masih ada, yang terbukti dengan adanya aktivitas spontanitas yang dilakukan sebagian masyarakat di Indonesia manakala ada masalah yang menimpa di lapisan masyarakat kurang beruntung lainnya. Hal tersebut merupakan potret potensi kepedulian sosial sebagai implementasi gotong royong."

Dengan mengimplementasikan dan mensosialisasikan gotong royong melalui platform media sosial, dapat dipahami bahwa fenomena digitalisasi informasi dan komunikasi dapat berkolaborasi dengan kearifan lokal. Nilai lokal itu lah yang menjadi kekuatan gerakan sosial Warga Bantu Warga. Selain menjadi titik sentral dalam gerakan, nilai lokal tersebut juga terbukti menjadi salah satu perekat antara pihak-pihak yang andil dalam gerakan ini. Implementasi kearifan lokal itu lah yang menjadi kekuatan kita sebagai masyarakat Indonesia. Berkaca pada pengalaman negara tetangga, bahwa pada saat angka Covid-19 di sana mengalami peningkatan yang signifikan dan melumpuhkan fasilitas kesehatan, yang terjadi adalah bahwa banyak sekali tenaga medis yang justru mengundurkan diri. Fenomena seperti itu tidak terjadi di Indonesia, dan salah satu alasannya adalah karena ada nilai gotong royong yang diaplikasikan menjadi aksi kolektif yang sistematis dan mampu membuat kita menghadapi bahkan keluar dari fase krisis dengan tetap tangguh dan bersama-sama. 


\subsection{Optimisme, Motivasi, dan Menebar Inspirasi sebagai Aspek Penggerak Gerakan Sosial}

Melalui analisis framingditemukan bahwa gerakan Warga Bantu Warga tidak secara dominan membingkai fenomena dari sudut pandang identifikasi masalah, dan tidak pula memposisikan suatu pihak sebagai penyebab permasalahan. Hal lainnya yang menarik dari gerakan ini adalah bahwa Warga Bantu Warga tidak membingkai pandemi dengan cara menebar ketakutan pada masyarakat. Hal ini terbukti dari unggahan para inisiator, kolaborator maupun masyarakat yang terkait dalam gerakan tersebut, bahwa tidak ada satupun yang menunjukkan bagaimana kacaunya kondisi Indonesia saat pandemi. Terlebih gerakan ini lahir pada Juli 2021 ketika kasus Covid-19 di Indonesia sedang parahparahnya. Namun tidak ada satu pun pembingkaian atau narasi yang memperlihatkan riuh dan penuhnya kondisi rumah sakit, kematian tenaga medis dalam jumlah yang massif, banyaknya galian pemakaman untuk korban Covid-19 yang meninggal dunia, ataupun kisruh masyarakat dengan aparat pemerintah dalam rangka penertiban usaha akibat dari kebijakan PPKM. Hal ini sangat berbeda dengan anggapan bahwa untuk memicu aksi kolektif, seseorang harus menebarkan rasa takut maupun perasaan akan adanya musuh bersama sebagai pihak yang patut disalahkan atas sebuah persoalan. Sekalipun banyak keterbatasan pemerintah dalam mengendalikan pandemi, tidak ada pembingkaian mengenai hal tersebut. Padahal media sosial merupakan platform yang potensial bagi masyarakat untuk menunjukkan kritik maupun gugatan pada pemerintah, seperti dengan mengajukan kritik berupa teks, meme, ataupun dengan petisi online. Alihalih menebarkan ketakutan dan kekecewaan kepada pemerintah atau menyalahkan pihak lain, narasi yang dibangun dalam gerakan ini seakan mengalihkan perhatian masyarakat untuk melihat pada apa yang bisa kita lakukan untuk membantu sesama dan dampak positif apa yang terjadi dari bantuan yang diberikan. Bahkan sebagai inovasi terbaru, salah satu inisiator dalam gerakan Warga Bantu Warga merilis sebuah inovasi yang bernama 'peta kebaikan'. Inovasi tersebut merupakan peta Indonesia secara virtual yang bisa diakses melalui gawai dan dilengkapi dengan titik-titik lokasi yang menyediakan bantuan, sehingga melalui fitur tersebut masyarakat Indonesia bisa mengetahui ketersediaan bantuan terdekat. Peta Kebaikan menguatkan optimisme masyarakat bahwa dalam kesulitan ini akan selalu ada bantuan dan kebaikan di sekitar, dan untuk menginspirasi orang untuk turut menyediakan bantuan. Selain itu, Warga Bantu Warga juga meluncurkan program baru Bernama 'Kawal Masa Depan', di mana melalui program tersebut masyarakat bisa mendaftar sebagai orang tua asuh dan memberikan bantuan untuk anak-anak yang orang tuanya meninggal karena Covid-19. Tidak hanya bantuan berupa finansial, namun dalam Kawal Masa Depan, akan dilakukan mentoring dan pendampingan untuk membimbing anak-anak yatim tersebut. Adanya Kawal Masa Depan sebagai salah satu inovasi terbaru dalam gerakan Warga Bantu Warga semakin mengukuhkan adanya optimisme bahwa gerakan ini akan terus berlangsung dalam jangka waktu yang panjang.

Melalui pembingkaian dalam gerakan Warga Bantu Warga, masyarakat diposisikan bukan hanya sebagai korban dari kondisi pandemi Covid-19, tetapi masyarakat sebagai 
agen perubahan. Jarangnya narasi mengenai keterlibatan pemerintah, secara implisit menunjukkan bahwa masyarakat tidak menunggu uluran tangan pemerintah, melainkan berdaya dan melakukan upaya sendiri dan kolektif. Selain itu unggahan-unggahan dalam gerakan Warga Bantu Warga selalu menggunakan diksi yang erat kaitannya dengan penguatan optimisme dan motivasi, seperti menyebut pengguna media sosial sebagai 'orang baik' atau 'kawan baik' dan kalimat-kalimat yang memotivasi untuk terlibat dalam membantu masyarakat terdampak. Sehingga hal tersebut menjadi sugesti dari pengguna media sosial untuk fokus kepada kebaikan yang bisa dilakukan.

Dalam aspek inspirasi, gerakan warga bantu sangat sering menunjukkan figur-figur dan kegiatan-kegiatan bantuan baik melalui gambar maupun video, seperti menunjukkan suatu komunitas yang mengadakan pasar gratis bagi masyarakat, relawan yang turun langsung dalam memberikan bantuan, atau kesuksesan bersama dalam mengumpulkan donasi dalam nominal yang besar. ini juga sering menyebarluaskan gambar ataupun video yang menunjukkan kesan para penerima bantuan yang merasa sangat terbantu dengan adanya gerakan ini. Kegiatan-kegiatan tersebut selalu disebarluaskan melalui platform media sosial, seperti Twitter sebagai salah satu motivational framing yaitu menebar inspirasi. Sehingga dari hal tersebut bisa dipahami kalau menguatkan aspek optimisme, motivasi, maupun inspirasi sangat potensial untuk menggugah perasaan dari masyarakat agar kemudian tertarik dan turut andil dalam suatu gerakan sosial. Hal itu juga sejalan dengan pendapat Castells (2012, h.13) bahwa

"Pada tingkat individu, gerakan sosial adalah gerakan emosional. Pemberontakan tidak dimulai dengan program atau strategi politik. Ini mungkin terjadi kemudian ketika kepemimpinan muncul dari dalam atau luar gerakan untuk mendorong politik, ideologis, dan agenda pribadi yang bisa jadi atau tidak berhubungan dengan asal-usul dan motivasi para peserta gerakan. Tapi ledakan besar gerakan sosial dimulai dengan transformasi emosi menjadi tindakan."

\subsection{Gerakan Sosial Digital Warga Bantu Warga dan Resiliensi Masyarakat Indonesia}

Mengacu pada anggapan teoritis yang kontradiktif mengenai peran media sosial dalam mewujudkan suatu gerakan sosial, penelitian ini menunjukkan bahwa penetrasi penggunaan media sosial menjadi manifestasi bagi kebangkitan masyarakat sipil dalam bergerak demi kemanfaatan bersama. Walaupun begitu, sejalan dengan pemikiran Lim (2014) bahwa media sosial bukan ranah yang tepat untuk mendalami wacana yang kompleks, sehingga untuk mentransformasikan aktivisme media sosial menjadi sebuah gerakan bergantung pada 'kemasan' yang ringan dan tampilan cuplikan. Apabila merujuk pada pendapat tersebut, gerakan sosial Warga Bantu Warga dapat berhasil dalam mentransformasikan aktivisme online menjadi sebuah gerakan sosial yang nyata dalam lingkup nasional karena pada prosesnya isu yang diangkat bukanlah sebuah persoalan yang rumit. Isu Covid-19 yang sebenarnya memiliki kompleksitas dalam aspek medis, sosial, maupun politis, disederhanakan sebagai pandemi yang mengharuskan masyarakat untuk bergerak semampunya dalam menolong sesama. Penyederhanaan 
narasi serta campaign dalam unggahan yang interaktif dan menarik menjadi salah satu kekuatan dari keberhasilan gerakan ini.

Gerakan sosial digital Warga Bantu Warga menjadi bukti resiliensi masyarakat Indonesia dalam merespons pandemi. Berdasarkan pemikiran Obrist et al. (2010, h. 283) resiliensi memiliki beberapa tingkatan antara lain tingkat yang paling rendah, menengah, dan yang paling tinggi. Pada tingkat yang paling rendah yaitu individu dapat melatih resiliensi dengan mempelajari kemampuan menghadapi gangguan; tingkat menengah adalah komunitas sosial atau masyarakat yang memiliki kekerabatan yang erat sehingga dapat bekerjasama untuk menangani bencana secara bersama-sama dan tingkat yang paling tinggi adalah adanya campur tangan pemerintah dalam membuat kebijakan sehingga dapat membantu masyarakat dalam menghadapi gangguan yang terjadi (Supriatna, E., Irwandi, \& Sari, A. L, 2020, h. 22). Pada kasus gerakan Warga Bantu Warga, dapat disimpulkan bahwa resiliensi yang terbentuk di masyarakat masih berada pada level menengah, di mana belum terdapat intervensi pemerintah dalam gerakan sosial ini. Walaupun begitu, hal ini sedikit berbeda dibandingkan pemikiran Obrist yang menyatakan bahwa pada level menengah resiliensi diwujudkan melalui kerjasama antar komunitas sosial atau masyarakat yang memiliki kekerabatan. Pada gerakan ini, terjadi kerjasama antar masyarakat luas di berbagai wilayah Indonesia dengan latar belakang yang berbeda, seperti individu, media, fundraising, dan lain sebagainya. Hal ini lah yang kiranya menjadi pembeda bahwa dengan pemanfaatan teknologi informasi kerjasama dapat dibentuk dari keragaman masyarakat yang sebelumnya tidak memiliki ikatan apapun, tetapi kemudian memiliki ketertarikan yang sama karena narasi yang dibangun melalui berbagai unggahan media sosial.

\section{Kesimpulan dan Saran}

Pemilihan Berdasarkan temuan dari hasil penelitian, maka dapat disimpulkan bahwa gerakan sosial digital Warga Bantu Warga merupakan salah satu bentuk dari resiliensi dan keberdayaan masyarakat Indonesia. Resiliensi masyarakat Indonesia yang ditunjukkan melalui gerakan ini masih berada pada level menengah, di mana pemerintah tidak melakukan intervensi pada gerakan Warga Bantu Warga. Adanya internet dan media sosial telah mendorong penyebaran nilai-nilai yang dinarasikan dan diperjuangkan oleh suatu gerakan. Walaupun gerakan ini berproses melalui internet, baik dari segi campaign maupun rekrutmen, Warga Bantu Warga berhasil memberikan dampak positif yang besar bagi masyarakat Indonesia, tidak hanya pada skala regional, tetapi sampai pada lingkup nasional. Dampak positif tersebut antara lain bantuan finansial, menguatkan UMKM, informasi yang valid, pendampingan secara psikologis, sampai pada program barunya yang bertujuan untuk memberikan orang tua asuh bagi anak-anak yang kehilangan orang tuanya karena Covid-19.

Dengan analisis framing, dapat dipahami bahwa salah satu kekuatan dari gerakan Warga Bantu Warga adalah menekankan ketangguhan dan keberdayaan masyarakat Indonesia, yang meliputi aspek gotong royong, kolaborasi dari berbagai pihak, maupun 
solidaritas masyarakat. Warga Bantu Warga lebih condong dalam pembingkaian mengenai solusi apa yang dapat dilakukan masyarakat untuk membantu sesama dan menekankan afirmasi positif, seperti optimisme, motivasi, maupun inspirasi. Berbeda dengan pembingkaian yang kerap kali terjadi pada gerakan sosial lainnya yang kental dengan menekankan ketidakadilan maupun viktimisasi, Warga Bantu Warga menggunakan cara menggugah empati masyarakat Indonesia untuk tergerak dan akhirnya terlibat dalam gerakan. Sehingga melalui gerakan tersebut terbukti bahwa untuk menggerakkan massa itu tidak hanya dapat dilakukan dengan narasi yang kritis dan provokatif.

Nilai lokal juga menjadi faktor yang sangat penting dalam gerakan sosial. Warga Bantu Warga merupakan salah satu bentuk implementasi kearifan lokal, yaitu gotong royong. Melalui gerakan ini modernisasi dan perkembangan teknologi menunjukkan bahwa dua hal tersebut mampu berkolaborasi dengan kearifan lokal. Lebih lanjut, gerakan Warga Bantu Warga telah mentransformasikan spirit gotong royong dalam ranah virtual. Implementasi nilai lokal dalam gerakan sosial inilah yang menjadi salah satu kekuatan masyarakat Indonesia dalam menghadapi pandemi Covid-19.

\section{Daftar Pustaka}

Brunnenmeier, Markus K. 2021. The Resilient Society. Colorado: Endeavor Literacy Press. Carty, Victoria. (2015). Social Movement and New Technologies. New York: Routledge Castells, Manuel. (2012). Networks of outrage and hope: social movements in the Internet age. Cambridge: Polity Press.

Eriyanto (2002). Analisis Framing, Konstruksi, Ideologi, dan Politik Media. Yogyakarta: PT. LKiS Pelangi Aksara

Irfan, Maulana. (2016). Metamorfosis Gotong Royong dalam Pandangan Konstruksi Sosial. Seminar Nasional Menuju Masyarakat Indonesia Sejahtera. Prosiding KS: Riset \& PKM, Volume: 4, Nomor 1 Hal: 1 - 140. ISSN: 2442-4480.

Jamil, Achmad. 2018. Social Movements in Framing Perspectives:A Study on Corruption Case Issues in Indonesia. Jurnal Komunikasi Indonesia Volume VII, Issue 2, July 2018. ISSN 2301-9816.

Ismail, Ahmad. (2012). Akademi Berbagi: Gerakan Sosial di Dunia Digital. Depok: Universitas Indonesia.

Mas'udi, dan Winanti (Ed). (2020). New Normal. Yogyakarta: Universitas Gajah Mada Press.

Keck, M., \& Sakdapolrak, P. (2013). What is social resilience? Lessons learned and ways forward. Erdkunde, 5-19

Kimhi, S.; Eshel, Y.; Marciano, H.; Adini, B. Fluctuations in National Resilience during the Covid-19 Pandemic. Int. J. Environ.Res. Public Health 2021, 18, 3876. https://doi.org/10.3390/ijerph18083876

Lim, Merlyna. (2014). Klik yang Tak Memantik: Aktivisme Media Sosial di Indonesia. Jurnal Komunikasi Indonesia Volume III Nomor 1. ISSN 2301-9816. 
Obrist, B., Pfeiffer, C., \& Henley, R. (2010). Multi- layered social resilience: A new approach in mitigation research. Progress in Development Studies, 10(4), 283-293

Subagyo. (2012). Pengembangan Nilai dan Tradisi Gotong Royong dalam Bingkai Konservasi Nilai Budaya. Indonesian Journal of Conservation Vol. 1 No. 1 - Juni 2012 (ISSN: 22529195).

Supriatna, E., Irwandi, \& Sari, A. L. (2020). The Vulnerability and Social Resilience of Indonesian Society in Facing the COVID-19 Pandemic. A Y E R JOURNAL, 27(2), 19 - 29

https://nasional.tempo.co/read/1484904/pandemi-Covid-19-gerakan-solidaritas-wargabantu-warga-meningkat diakses pada 20 Agustus 2021. 